\title{
ЛИТОЛОГО-ФАЦИАЛЬНАЯ ЗОНАЛЬНОСТЬ РАННЕТРЕМАДОКСКОГО ОСАДКОНАКОПЛЕНИЯ НА ВОСТОЧНО-ЕВРОПЕЙСКОЙ ПЛАТФОРМЕ
}

Базальные слои ордовика на Восточно-Европейской платформе представлены терригенными песчано-глинистыми отложениями раннетремадокского возраста, распространение которых приурочено в основном к западным и центральным частям ее (рис. 1). Предшествующий тремадоку период на бо́льшей части территории платформы характеризуется континентальными условиями. Глубина эрозионного среза дотремадокского размыва в разных частях территории разная, в общих чертах уменьшаясь к западу (северо-западу) - к краевым частям платформы.

При составлении настоящего обзора использованы в основном литературные данные. Детальные литологические исследования нижнетремадокских отложений на территории Северной Эстонии и сравнительное описание обнажений Ленинградской области (Северо-Прибалтийский регион) проведены автором.

Нижнетремадокские отложения на Восточно-Европейской платформе в пределах Советского Союза объединены в пакерортский горизонт (Решения ..., 1978). В Норвегии к рассматриваемому интервалу относятся диктионемовые сланцы зоны $2 e$ (Henningsmoen, 1960), в Швеции - диктионемовые сланцы (Tjernvik, 1956), в Польше - кшижанские слои (Znosko, 1964; Szymański, 1973).

Исходя из литологического строения нижнетремадокских отложений, территорию Восточно-Европейской платформы можно подразделить на пять регионов с различным литолого-фациальным типом осадконакопления (рис. 1,2 ). Переход от одного типа к другому осуществляется чаще всего постепенно, поэтому между выделенными регионами существуют территории с переходным характером разреза.

I Южно-Скандинавски й регион (грабен Осло, юг Швеции, о-в Борнгольм). Это западная краевая. часть платформы, непосредственно прилегающая к каледонской геосинклинальной области. Нижний тремадок представлен здесь полностью однообразной толщей темных, обогащенных органическим веществом глинистых сланцев или аргиллитов (диктионемовых сланцев) с темными глинисто-карбонатными конкрециями (stinkstone) (рис. 2). Мощность диктионемовых сланцев в разрезах этого типа колеблется от первых десятков сантиметров до 16,5 м (Tjernvik, 1956; Thorslund, Axberg, 1980; Bergström, 1982; Jaanusson, $1982 c)$.

Переход от подстилающих верхнекембрийских квасцовых сланцев к диктионемовым осуществляется без изменения литологического облика и границу между ними можно установить лишь на основании изучения фауны. Непрерывностью осадконакопления при переходе от кембрия к ордовику характеризуются разрезы в Осло-Сконенской депрессии (Hen- 
ningsmoen, 1960; Bruton и др., 1982; Erdtmann, 1982; Jaanusson, 1982a). В Вестер- и Эстергётланде литологический тип разреза сходный, но на границе кембрия-ордовика появляется стратиграфическое несогласие - в ордовикской части разреза из пяти выделенных в нижнем тремадоке граптолитовых зон выпадают одна или две нижние (Erdtmann, 1982; Jaanusson, 1982b).

В северной части о-ва Эланд в основании разреза тремадока пол диктионемовыми сланщами появляется маломощный $(0,02$ м) прослой конгломерата с Obolus sp. (Tjernvik, 1956; Jaanusson, Mutvei, 1982). Тем самым, нижнетремадокский разрез Восточной Швеции по литологическому строению в принципе сходен с Северо-Прибалтийским.

II Северо-Прибалтийский регион (Запалная и Северная Эстония и северная часть Ленинградской области). Нижний тремадок (пакерортский горизонт) в нижней части разреза представлен оболовыми песчаниками, а в верхней - граптолитовыми аргиллитами (диктионемовыми сланцами) .

Среди оболовых песчаников Западной Эстонии преобладают светлые слабосцементированные мелкозернистые песчаники или крупнозернистые алевролиты, содержащие детрит или целые створки фосфатных беззамковых брахиопод. Доля среднезернистых песчаников в оболовой толще относительно скромная, но к ним всегда приурочены более богатые скопления детрита или целых створок фосфатсодержащих брахиопод, образующие т. н. «оболовый конгломерат» или оболовый детритит, в которых фосфатный материал имеет породообразующее значение. «Оболовый конгломерат», кроме относительно мелкого детрита, содержит целые или почти целые створки беззамковых брахиопод. Общее количество фосфатного материала в брахиоподовом ракушечнике обычно составляет $20-60 \%$ от всей породы, в редких случаях $90 \%$.

На описываемой территории Западной и Северной Эстонии еоболовый конгломерат» почти повсеместно залегает в основании разреза пакерортского горизонта. Мощность его чаще всего составляет несколько сантиметров, но местами доходит до нескольких метров. На отдельных участках в нижней части разреза пакерортского горизонта встречены два или даже три прослоя брахиоподового ракушечника (район Маарду, восточнее г. Таллина). При мощностях 1 м и более, брахиоподовый ракушечник представляет интерес в качестве фосфатного сырья. Самым крупным месторождением такого типа можно считать месторождение Раквере в средней части Северной Эстонии, где средняя мощность брахиоподового ракушечника и детритита составляет примерно 3 м при среднем содержании $\mathrm{P}_{2} \mathrm{O}_{5}$ около $10 \%$ (т. е. около $30 \%$ обломков фосфатсодержащих брахиопод) (Раудсеп, Эскель, 1980).

В описываемом типе разрезов над ракушечником залегают кварцевые мелкозернистые песчаники .или крупнозернистые алевролиты с редким детритом брахиопод, чередующиеся с прослоями темных граптолитовых аргиллитов. Находки остатков граптолитов в прослоях аргиллитов позволяют заключить, что нижняя граптолитовая зона «ослоского стандарта» отсутствует и в Северной Прибалтике (Кальо, 1974; Кальо, Кивимяги, 1970, 1976). Мощность оболовых песчаников изменчива - от десятков сантиметров до 22 м (Хейнсалу, 1981).

Верхняя часть пакерортского горизонта в Западной Эстонии и в северной приглинтовой части Ленинградской области сложена темнокоричневыми плотными горизонтальнослоистыми граптолитовыми аргиллитами. Местами в нижней части толщи граптолитовых аргиллитов наблюдаются прослои светлых кварцевых алевролитов мощностью в несколько сантиметров. В граптолитовых аргиллитах часто встречаются конкреции или рассеянные мелкие кристаллики пирита, а также ра- 


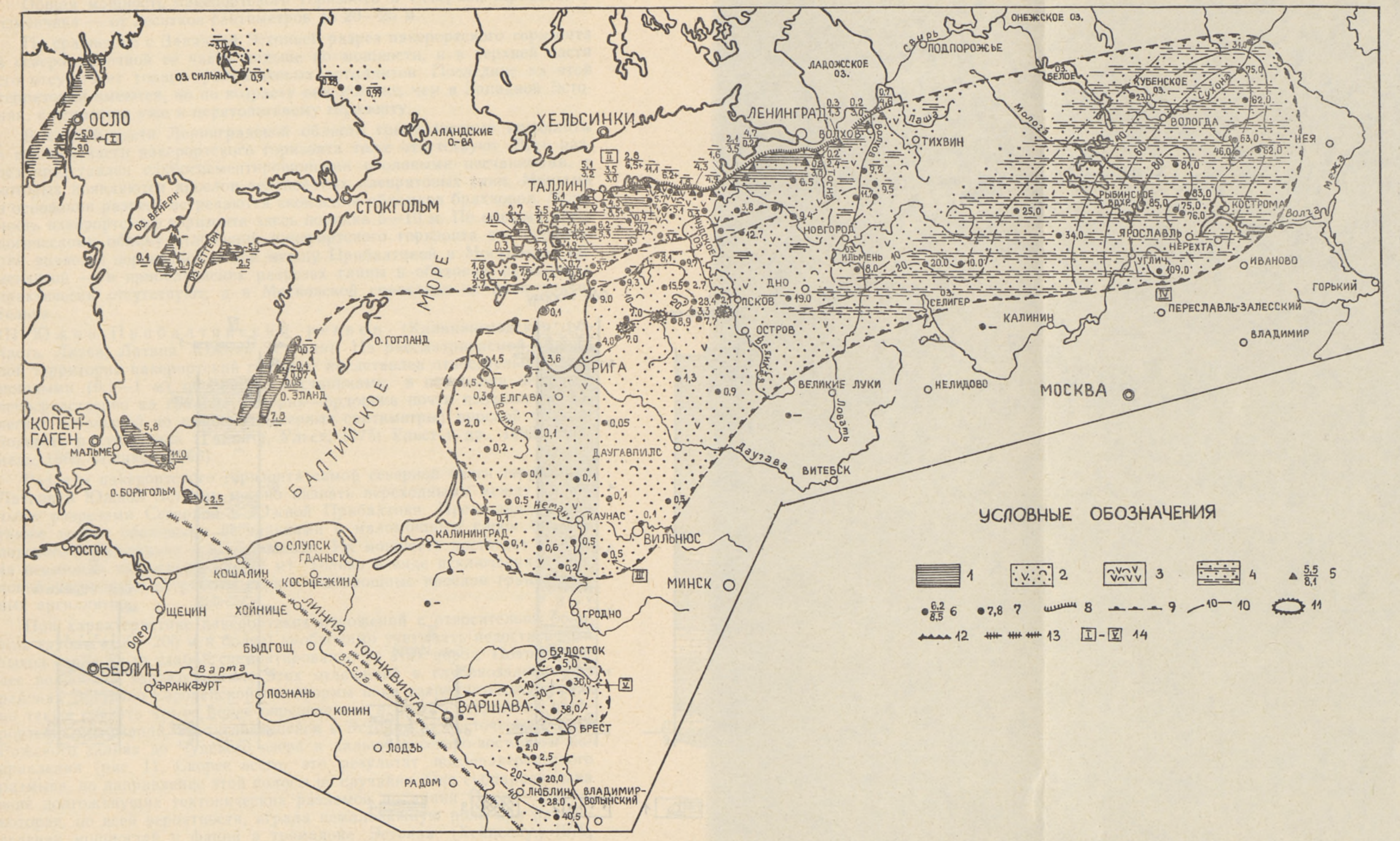

Рис. 1. Литолого-фациальная карта раннего тремадока Восточно-Европейской платформы. 1 - граптолитовый аргиллит; 2 - кварцевый песчаник или алевролит с обломками брахнопод; 3 - брахиоподовый ракушечник (оболовый фосфорит); 4 - чередование песчано-глинистых пород; 5 - обнажения (в числителе мощность граптолитовых аргиллитов, м; в знаменателе - оболовых песчаников); 6 - буровые скважины, то же, м; 7 - буровые скважины, мощность оболовых песчаников (или песчано-глинистых пород), м; 8 - Балтийско-Ладожский глинт; 9 - современная гранища распространения нижнетремадокских отложений; 10 - изопахиты, м; 11 - Валмиера-Мынисте-Локновские выступы кристаллического фундамента; 12 - надвиг на платформу; 13 - линия Торнквиста; 14 - разрезы (см. рис. 2). 


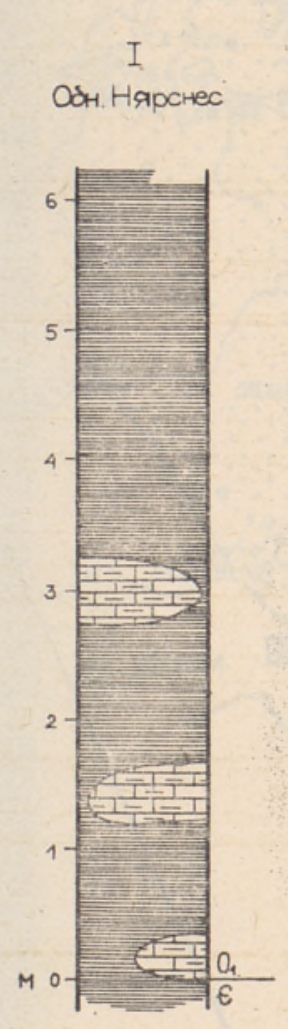

OSH. Maapgy
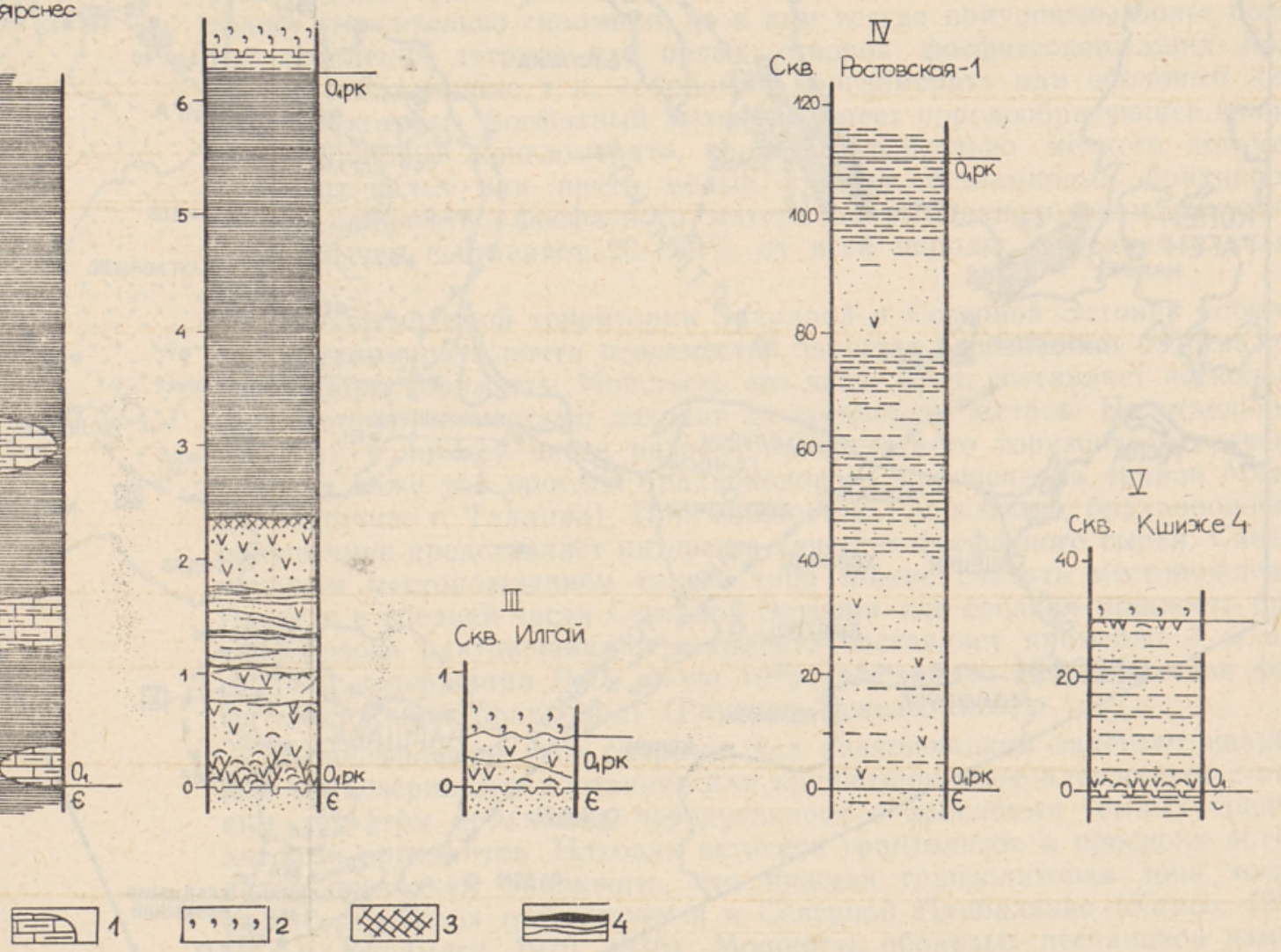

Рис. 2. Литологические типы разрезов. I - обн. Нярснес (Южно-Скандинавский тип), II - обн. Маарду (Северо-Прибалтийский), III - скв. Илгай (Южно-Прибалтийский), IV - скв. Ростовская (Московская синеклиза), V - скв. Кшиже (Польский тип). 1 - глинисто-карбонатные конкреции (stinkstone), 2 - глауконит, 3 - пирнт, 4 - прослои граптолитовых аргиллитов. (Остальные усл. обозн. см. на рис. 1). 
диальнолучистые конкреции антраконита. Мощность аргиллитов на территории их развития меняется от десятков сантиметров до 7 м на Северо-Западе Эстонии (Хейнсалу, 1980).

Общая мощность пакерортского горизонта в Северной Прибалтике нзменчива - от десятков сантиметров до 20-25 м.

По сравнению с Западной Эстонией разрез пакерортского горизонта в северо-восточной ее части меньше по мощности, и в верхней части его отсутствует толща граптолитовых аргиллитов. Последние на этой территории имеются, но по возрасту они моложе, чем в Западной Эстонии, и относятся уже к цератопигевому горизонту.

В южной части Ленинградской области граптолитовые аргиллиты в верхней части пакерортского горизонта тоже отсутствуют. Весь разрез представлен слабосцементированными оболовыми песчаниками, в которых появляются прослои зеленоватых алевритовых глин. Местами в основании разреза встречаются скопления обломков брахиопод. Мощность пакерортского горизонта здесь порядка 5-10 м. По общему литологическому облику отложений пакерортского горизонта эта территория является переходной зоной между Прибалтикой и Московской синеклизой - в прибалтийских разрезах глины в оболовых песчаниках практически отсутствуют, а в Московской синеклизе их доля значительна.

III Ю жно-П риб а л ти й с и й ре ги он (Калининградская область, Литва, Латвия, Южная Эстония). На рассматриваемой обширной территории пакерортский горизонт представлен относительно маломощными $(0,1-1$ м) оболовыми песчаниками, в основании которых, непосредственно на границе кембрия-ордовика почти повсеместно залегает небольшой по мощности (первые сантиметры) прослой брахиоподового ракушечника (Гайлите, Ульст, 1975; Ульст и др., 1982; Мянниль, 1966; Лашков, 1968).

Разрезы пакерортского горизонта самой северной части территории Латвии и Южной Эстонии можно назвать переходными между типичными разрезами Северной и Южной Прибалтики. Представлены они также только оболовыми песчаниками с маломощным слоем брахиоподового ракушечника в их основании. Их мощность достигает $8-9$ м (в некоторых скважинах 15-25 м). Только в виде исключения в оболовых песчаниках встречены редкие маломощные прослои граптолитовых аргиллитов.

При характеристике пакерортских отложений с относительно больших глубин (100-200 м и более) необходимо учитывать недостаточный выход керна из-за слабой сцементированности этих пород. Поэтому более подробная характеристика этих отложений в глубокозалегающих районах Восточно-Европейской платформы пока затруднительна. Трудно также сказать что-то более определенное о полосе отсутствия пакерортских отложений, протягивающейся в Эстонии от восточного берега Рижского залива до Чудского озера и дальше в северо-восточном направлении (рис. 1). Скорее всего, это результат послепакерортского размыва, но направление этой полосы не случайно. Она субпараллельна зоне долгоживущих тектонических разломов по линии Пярну-Нарва, которая, по всей вероятности, играла немаловажную роль при распределении мощностей и фаций в тремадоке Эстонии (Хейнсалу, 1979, 1981).

IV C реднерусскй рег и он (Московская синеклиза) охватывает обширную территорию Новгородской, Вологодской и Ярославской областей.

В восточной части Московской синеклизы пакерортский горизонт представлен относительно мощной толщей преимущественно глинистых 
отложений, в которых встречены остатки беззамковых брахиопод (Дмитровская, 1980). Нижняя часть разреза горизонта более песчанистая, представленная серыми и зеленовато-серыми кварцевыми алевролитами и желтовато-серыми, преимущественно мелкозернистыми песчаниками (Рыбникова, Стриковская, 1984). В верхней части пакерортского горизонта преобладают темно-серые с зеленоватым оттенком тонкоплитчатые алевритистые плотные глины, чередующиеся с зеленовато-серыми глинистыми плотными кварцевыми алевролитами.

Максимальные мощности пакерортских отложений для Московской синеклизы и для всей Восточно-Европейской платформы $(80-100$ м) установлены в восточной части синеклизы в субмеридиональном направлении по оси Вологда-Ростов. В западной половине синеклизы мощности его уменьшаются до 30-10 м (Станкевич, 1961; Моисеенко, Александрова, 1963).

$\mathrm{V}$ Восточно-Польский регион (районы Бяловежи и Люблинщины). Нижнетремадокские отложения вскрыты рядом буровых скважин в Подлясско-Брестской впадине в районе Бяловежи (Znosko, 1964; Szymański, 1973). Литологически он представлен двумя толщами оболовых песчаников, разделенных коричневато-зеленоватыми песчаноглинистыми отложениями или аргиллитами мощностью $4-6$ м. Глинистые прослои встречаются и в оболовых песчаниках. Как в нижних, так и в верхних оболовых песчаниках описан Obolus apollinis Eichw. Общая мощность оболовой толщи пакерортского горизонта в Подлясско-Брестской впадине порядка $30-40$ м, уменьшаясь в непосредственной близости Белорусско-Мазурской антеклизы до 5 м.

Местами в описываемом районе на оболовых песчаниках встречены и граптолитовые (диктионемовые) аргиллиты мощностью 1,9-2,0 м.

Дальше к югу (вдоль юго-западного края Восточно-Европейской платформы), в районе Люблинщины имеется наиболее южное местонахождение отложений тремадокского возраста. Отложения нижнего тремадока здесь обнаружены в нескольких скважинах. Представлены они толщей чередующихся песчано-глинистых отложений (Lendzion и др., 1979), их мощность составляет 20-40 м, уменьшаясь к северу, в сторону Лукувско-Вишницкого горста до первых метров, а местами даже до $0,1 \mathrm{~m}$.

Вышеизложенный материал позволяет сделать следующие палеогеографические выводы.

Начало ордовика на Восточно-Европейской платформе ознаменовалось достоверным развитием моря только на крайнем западе ее. Изучение граптолитов показывает, что непрерывное осадконакопление при переходе от кембрия к ордовику существовало только в самой краевой части платформы в депрессии Осло-Сконе, где без перемены условий осадконакопления в течение длительного времени в тиховодной морской восстановительной обстановке отлагались глинистые обогащенные органикой диктионемовые илы. Районы, прилегающие к этой депрессии с востока - Вестер- и Эстергётланд, южная часть о-ва Эланд - отличались от нее тем, что на самых ранних стадиях тремадока здесь существовали условия нулевой седиментации (о чем свидетельствует отсутствие одной или двух нижних граптолитовых зон). Дальше, без видимых следов перерыва в течение всего тремадока здесь отлагались также диктионемовые илы.

К востоку, ориентировочно восточнее линии оз. Сильян-север о-ва Эланд-Варшава, относительно глубоководные условия осадконакопления в тремадокском бассейне сменились мелководными. На обширной территории Прибалтики, в восточных районах Южной Швеции (оз. Сильян, север о-ва Эланд), а также в районе Бяловежи (Восточная Польша) тремадокское осадконакопление началось с нагромож- 
дения конгломератов илй брахиоподового ракушечника, а выше по разрезу осаждались оболовые пески и алевриты. На границе кембрияордовика наблюдается литологически четко выраженный перерыв.

Южная Прибалтика (Калининградская область, Литва, значительная часть Латвии) в раннем тремадоке представляла собою обширное мелкое море. Судя по характеру сохранившихся отложений, море существовало здесь относительно недолго. Все же не следует считать такой вывод неоспоримым, поскольку верхняя часть отложений могла быть размыта.

В Северной Прибалтике и в Восточной Польше (район Бяловежи) ход осадконакопления в раннетремадокском море определялся по-видимому, дифференцированными тектоническими подвнжками дна бассейна, которые приводили к расчленению рельефа ложа. В условиях мелкого моря этого было достаточно для того, чтобы на ранней стадии тремадокского моря накапливались разнофациальные отложения: оболовые песчано-алевритовые породы, брахиоподовые ракушечники и скопления детрита, прослои или линзы граптолитовых аргиллитов. K концу раннего тремадока в Северной Прибалтике и в районе Бяловежи условия осадконакопления приблизились к таковым Осло-Сконенской депрессии. По-видимому, на территории Финского залива, Северной Эстонии и севера Ленинградской области образовалась вытянутая в субширотном направлении относительно узкая и на фоне общего мелководья несколько более глубоководная часть моря. Аналогичное узкое вытянутое углубление образовалось в конце раннего тремадока и в Польше вдоль юго-западного края платформы. В обеих относительно глубоководных частях (Северо-Прибалтийской и Польской) моря в восстановительной среде, практически в неподвижной воде, отлагались диктионемовые илы. По всей вероятности, эти ответвления тремадокского моря имели прямую связь с Западной Швецией и Ослоским регионом, где диктионемовые илы отлагались в течение всего тремадока.

Московская синеклиза как самая крупная отрицательная структура того времени на Восточно-Европейской платформе, где шло накопление песчано-глинистых осадков, была относительно глубоководной уже в раннем тремадоке. По устному сообщению Ю. Е. Дмитровской, Московская синеклиза имела связь не только с Прибалтийской частью моря, но и через Пачелмский прогиб была связана с Уралом и Казахстаном. Сходство раннетремадокских отложений Московской синеклизы и ЮгоВосточной Польши (район Люблинщины) позволяет предполагать связь и между этими частями бассейна.

Автор выражает искреннюю благодарность В. С. Ванчугову, В. Ю. Горянскому и Ю. Е. Дмитровской за консультацию по части Ленинградской области и Московской синеклизы, предоставленную при составлении литологофациальной карты раннего тремадока.

\section{ЛИТЕРА ТУРА}

Боровко Н. Г., Сергеева С. П., Волкова Н. А., Галуб И. Н., Горянский В. Ю., Попов Л. Е., Хазанович K. К. Опорный разрез пограничных отложений кембрия и ордовика Северо-Запада Русской плиты (р. Ижора). - Изв. АН СССР. Сер.

геол., 1984 , № 7, $54-63$.
Дмитровская Ю. Е. История развития Московского бассейна в ордовикское время. Изв. АН СССР. Сер. геол., 1980, № 10, 154-157. 
Гайлите Л. К., Ульст Р. Ж. Стратиграфия и фауна нижнего ордовика Латвии. В кн.: Геология кристаллического фундамента и осадочного чехла Прибалтики. Рига, $1975,82-128$.

Кальо Д. Л. О граптолитовых зонах тремадока и аренига Прибалтийской и Московской синеклиз. - В кн.: Граптолиты СССР. М., 1974, 31-36.

Кальо Д. Л., Кивимяги Э. К. О распределении граптолитов в диктионемовом сланце Эстонии и разновозрастности его фацнй, - Изв. АН ЭССР. Хим. Геол., 1970, 19, № 4, 334-341.

Кальо Д. Л., Кивимяги Э. К. Зональное расчленение тремадока Эстонии. - В кн.: Граптолиты и стратиграфня. Таллин, 1976, 56-63.

Лашков E. М. Литостратиграфические комплексы ннжнего ордовика Южной Прибалтики. - В кн.: Стратиграфия нижнего палеозоя Прибалтики и корреляция с другими регионами. Вильнюс, $1968,139-154$.

Моисеенко В. С., Александрова Е. П. Валдайская опорная скважина (Новгородская область). - Тр. ВНИГРИ, вып. 221, Л., 1963.

Мянниль Р. М. История развития Балтийского бассейна в ордовике. Таллин, 1966.

Paydcen P. B., Эскель Ю. Особенности геологического строения фосфоритоносной толщи южнее месторождения Тоолсе. - Изв. АН ЭССР. Геол., 1980, 29, № 2, $84-86$.

Решения Межведомственного регионального стратиграфического совещания по разработке унифицированных стратиграфических схем Прибалтики, 1976. Л., 1978.

Рыбникоеа М. В., Стриковская Е. М. Расчленение нижнеордовикских терригенных отложений Московской синеклизы. - Сов. геол., 1984, № 4, 45-51.

Станкевич Л. И. Пестовская опорная скважина (Новгородская область). - Тр. ВНИГРИ, вып. 182, Л., 1961.

Ульст Р. Ж., Гайлите Л. К., Я̆ковлева В. И. Ордовик Латвни. Рнга, 1982.

Хейнсалу X. Н. О влиянии тектоники на ракушечное фосфатонакопление в раннетремадокском бассейне. - Изв. АН ЭССР. Геол., 1979, 28, № 3, 89-93.

Хейнсалу X. H. Фациальные соотношения верхнетремадокских отложений Северной Эстонин. - Изв. АН ЭССР. Геол., 1980, 29, № 1, 1-7.

Хейнсалу $X . H$. Литология фосфатоносных отложеннй тремадока Северной Эстонни. Автореф. канд. дис. Таллин, 1981.

Bergström, J. Scania. - In: Field Excursion Guide. IV International Symposium of the Ordovician System. Paleontological Contributions from the University of Oslo, N 279. Oslo, 1982, 184-191.

Bruton, D. L., Erdtmann, B.-D., Koch, L. The Naersnes section, Oslo Region, Norway: a candidate for the Cambrian-Ordovician boundary stratotype at the base of the Tremadoc Series. - In: The Cambrian-Ordovician Boundary: Sections, Fossil Distributions and Correlations. Cardiff, 1982, 61-69.

Erdtmann, B.-D. Palaeobiogeography and environments of planktic dictyonemid graptolites during the earliest Ordovician. - In: The Cambrian-Ordovician Boundary: Sections, Fossil Distributions and Correlations. Cardiff, 1982, 9-27.

Henningsmoen, G. Cambro-Silurian deposits of the Oslo region. - In: Geology of Norway (ed. Olaf Holtedahl). Norges Geologiske undersökelse, N 208. Oslo, $1960,130-150$.

Jaanusson, $V$. Introduction to the Ordovician of Sweden. - In: Field Excursion Guide. IV International Symposium on the Ordovician System. Paleontological Contributions from the University of Oslo, N 279. Oslo, 1982a, 1-9.

Jaanusson, V. Ordovician in Västergötland. - In: Field Excursion Guide. IV International Symposium of the Ordovician System. Paleontological Contributions from the University of Oslo, N 279. Oslo, 1982b, 164-175.

Jaanusson, V. The Siljan district. - In: Field Excursion Guide. IV International Symposium of the Ordovician System. Paleontological Contributions from the University of Oslo, N 279. Oslo, 1982c, 15-29.

Jaanusson, V., Mutvei, H. Ordovician of Oland. - Guide to Excursion 3. IV International Symposium on the Ordovician System. Oslo, 1982, 1-23.

Lendzion, K., Modlinski, Z., Szymański, B. Tremadok Lubelszczyzny, - Kwartalnik geologiczny, 1979, 23, N 4, 713-726.

Szymański, B. Osady tremadoku i arenigu na obszarze Białowieży. - Prace Inst. Geol., 1973, 69, 3-92.

Thorslund, P., Axberg, S. Geology of the southern Bothnian Sea. Part I. - In: Bulletin of the Geological Institutions of the University of Uppsala. New series, 8, Uppsala, 1980, 35-62.

Tjernvik, $T$. E. On the Early Ordovician of Sweden. Stratigraphy and Fauna. Publication of the University of Uppsala, N 9, 1956, 1-185.

Znosko, J. Ordowik obszaru Bialowieży i Mielnika. - Kwartalnik geologiczny, 1964, $8, \mathrm{~N} \mathrm{1,60-72.}$ 


\section{VARATREMADOKIAEGSETE SETETE LITOFATSIAALSEST TSONAALSUSEST IDA-EUROOPA PLATVORMIL}

Alamtremadoki setete levikualal Ida-Euroopa platvormil on eraldatud 5 regiooni, mis erinevad oma litoloogilise ehituse poolest: I - Lōuna-Skandinaavia, II - Pōhja-Baltikum, III - Lōuna-Baltikum, IV - Kesk-Venemaa, V - Ida-Poola. Iga ala kohta on lisatud sellele alale tüüpiline litoloogiline läbilổige. Varatremadokiaegse basseini paleogeograafias eralduvad: 1) Oslo-Scania depressioon, geosünklinaalse mere lähedane ala, kus stagnatsiooni tingimustes settisid diktüoneemakildad; 2) Baltikumi ala koos Ida-Poolaga (Bialowieża), midagi madalaveelise veealuse platoo taolist, kus settisid obolusliivad ja «oboluskonglomeraat». Varatremadoki lôpul moodustus Pōhja-Baltikumis lääne-idasuunaline suhteliselt süvaveelisem mere osa, kus nagu Rootsi aladel settisid diktüoneemamudad. Seos Oslo-Scania aladega mööda platvormi edelaserva oli arvatavasti ka Białowieża rajoonil Ida-Poolas, kus varajase tremadoki lōpul samuti settisid diktüoneemamudad; 3) Moskva sünekliis, platvormi suhteliselt püsivate vajumiste ala, varatremadokiaegse mere laialdane süvaveeline osa - liivade-savide settimisala, mis oletatavasti oli seotud Kagu-Poola aladega.

Heljo HEINSALU

\section{THE LITHOFACIAL ZONALITY OF EARLY TREMADOC DEPOSITS IN THE EAST-EUROPEAN PLATFORM}

Five regions of a different lithological composition have been distinguished in the distribution area of the Lower Tremadoc deposits in the East-European Platform (Fig. 1): I - South Scandinavia, II - North Baltic, III - South Baltic, IV Central Russia, V - East Poland. The lithological section typical of each region has been added correspondingly (Fig. 2). In the palaeogeography of the Early Tremadoc basin, the following areas can be stated: 1) the Oslo-Scania depression, an area close to the geosynclinal sea where Dictyonema shale is deposited under stagnation conditions; 2) the Baltic region together with eastern Poland (Bialowieźy), a kind of underwater plateau with a low water level, where Obolus sandstone and «Obolus conglomerate» are deposited. In North Baltic, at the end of the Early Tremadoc, a part of the sea with relatively deeper water conditions was formed in the EW direction, where (like in the areas of Sweden) Dictyonema muds were distributed. The Bialowieźy region in East Poland, where Dictyonema muds are also deposited at the end of the Early Tremadoc, was probably connected with the Oslo-Scania area along the SW margin of the platform; 3) the Moscow syneclise, a section of the platform with a considerably constant sinking and extensive deep-water part of the Early Tremadoc sea, deposition areas af sands and clays, presumably connected with the SE Polish territory (Lubelszezyzny). 